Гандзюк Д.М., Гандзюк М.О., Стельмащук В.В.

Луиький наиіональний технічний університет, Луцьк, Украйна

\title{
ВИЗНАЧЕННЯ НОРМАЛЬНИХ РЕАКЦЙ ОПОРНОЇ ПОВЕРХНІ ПРИ РУСІ МОДУЛЬНОГО ТРИЛАНКОВОГО ПРИЧІПНОГО АВТОПОӤЗДА УСКЛАДІ «АВТОМОБІЛЬ-ТЯГАЧ - ДВОВІСНИЙ ПІДКАТНИЙ ВІЗОК - ТРИВІСНИЙ НАПІВПРИЧІП» У ГАЛЬМІВНОМУ РЕЖИМІ
}

\footnotetext{
Ефективним засобом скорочення чисельності транспортних засобів при збереженні обсягів вантажоперевезень $€$ використання автопоїздів. У наш час автопоїзди застосовуються у багатьох країнах світу. Зважаючи на відносну конструктивну простоту та меншу довжину при однаковому рівні вантажопідйомності, та з урахуванням ряду інших переваг, сідельні автопоїзди отримали значне визнання й найбільш поширені у забезпеченні транспортних перевезень вантажів.

3 огляду на зростання інтенсивності руху на сучасних автомагістралях, необхідно підвищити безпеку транспортних засобів для уникнення аварійних ситуацій, що несуть за собою погіршення здоров'я людей та значні матеріальні втрати при пошкодженні транспортних засобів та вантажів. Особливо гостро це питання стосується автомобільних поїздів, процес руху та гальмування яких набагато складніший ніж в одиничних автомобілів. Необхідно щоб гальмівна система дозволяла регулювати швидкість руху автопоїзда у широкому діапазоні, протидіяла заносам, а також унеможливлювала складання ланок транспортного засобу та його зіткнення з іншими автомобілями, тобто забезпечувала відповідну стійкість. Водій повинен максимально контролювати поведінку транспортного засобу під часу руху, а за потреби швидко та безпечно зупинити його.

Зважаючи на це, поліпшення експлуатаційних властивостей автопоїздів у сучасних умовах руху $\epsilon$ одним із пріоритетних завдань для забезпечення високого рівня безпеки їх експлуатації з максимальною ефективністю використання. Досягнення даних вимог можливе лише за умови врахування можливих змін технічного стану автопоїздів у процесі експлуатації. Зокрема, значну увагу слід відвести змінам, які можуть відбутися у гальмівній системі ланок автопоїзда, що можуть спричинити порушення оптимальних показників регулювання й розподілу гальмівних сил по осях та бортах транспортного засобу, що неминуче призводить до втрати стійкості його руху навіть при незначних швидкостях, особливо при максимальному завантаженні.

Вирішення цих проблем неможливе без розробки математичної моделі руху модульного триланкового причіпного автопоїзда, у якій були б враховані основні кінематичні та геометричні співвідношення, кути встановлення осей, нормальні реакції опорної поверхні та бічні сили на колесах осей ланок з урахуванням їх перерозподілу по осях та бортах при гальмуванні автопоїзда у криволінійному та прямолінійному русі а також кути відведення коліс автомобіля-тягача, підкатного візка та напівпричепа.

Саме тому дана робота присвячена визначенню нормальних реакцій опорної поверхні при русі модульного триланкового причіпного автопоїзда у складі «автомобіль-тягач - двовісний підкатний візок тривісний напівпричіп» у гальмівному режимі.

Ключові слова: автопоїзд; модульний триланковий причіпний автопоїзд; компонувальна схема; причіпна ланка; причіп; напівпричіп; підкатний візок; математична модель; експлуатаційні властивості; стійкість; опорна поверхня; нормальні реакції; гальмівний режим
}

\section{ВСТУП}

Для досягнення високих показників продуктивності використання автопоїздів при здійсненні вантажоперевезень необхідно створити умови для їх експлуатації з максимальною ефективністю, тобто із максимальним завантаженням та при русі на максимальних швидкостях. Для цього, в першу чергу, потрібно забезпечити дотримання даними транспортними засобами основних експлуатаційних властивостей, що визначають безпеку руху. Серед найбільш важливих техніко-експлуатаційних властивостей автопоїздів, що забезпечують безпеку їх руху, варто виокремити стійкість, зокрема у гальмівному режимі. Адже втрата стійкості часто приводить до створення дорожньо-транспортних пригод, що супроводжуються травмуванням та значними матеріальними втратами.

Характер руху автопоїзда принципово відрізняється від руху одиничного автомобіля. Відмінність можна пояснити наявністю додаткових зусиль, що виникають у шарнірному з'єднанні ланок транспортного засобу, а також сил і моментів, які діють на його окремі ланки та рух транспортного засобу в цілому. Особливо помітним $€$ їх вплив при гальмуванні автопоїзда, яке може супроводжуватися складанням ланок та втратою стійкості транспортного засобу. Це пояснюється тим, що у процесі гальмування на автомобіль діють сили та моменти в різних площинах та напрямах. Під їх впливом змінюється навантаження окремих коліс. Вплив бічних сил призводять до перевантаження коліс одного борту транспортного засобу, а також може спричинити відведення або ковзання його коліс. 


\section{АНАЛІЗ ЛІТЕРАТУРНИХ ДАНИХ ТА ПОСТАНОВКА ПРОБЛЕМИ}

Вирішення проблем, пов'язаних з безпекою руху триланкових автопоїздів не розв'язується тільки застосуванням електронних систем: автоматичного усунення блокування колеса (АБС), системи розподілу гальмівних зусиль (EBD), системи стабілізації руху (ESP), та інших. Такі системи дозволяють значно покращити гальмівні властивості автотранспортних засобів, підвищити стійкість триланкового автопоїзда у гальмівному режимі.

Характер руху автопоїзда принципово відрізняється від руху одиничного автомобіля. Відмінність можна пояснити наявністю додаткових зусиль, що виникають у шарнірному з'єднанні ланок транспортного засобу, а також сил і моментів, які діють на його окремі ланки та рух транспортного засобу в цілому. Особливо помітним $є$ їх вплив при гальмуванні автопоїзда, яке може супроводжуватися складанням ланок та втратою стійкості транспортного засобу. Це пояснюється тим, що у процесі гальмування на автомобіль діють сили та моменти в різних площинах та напрямах. Під їх впливом змінюється навантаження окремих коліс. Вплив бічних сил призводять до перевантаження коліс одного борту транспортного засобу, а також може спричинити відведення або ковзання його коліс.

Проблемі стійкості руху автомобіля та автопоїзда присвячено багато робіт, оскільки вона є важливою характеристикою, яка визначає його поведінку під впливом зовнішніх факторів. Дослідженню стійкості транспортних засобів при гальмуванні присвячені роботи Чудакова Є.О., Певзнера Я.М., Ляпунова О.М., Фалькевича Б.С., Литвинова А.С., Косолапова Г.М., Хачатурова А.А., Антонова Д.А., Закіна Я.Х., Ревіна О.О., Малюгіна П.М., Соцкова Д.О., Хамова І.В., Ревіна С.О., Солнцева О.М., Сахна В.П., Полякова В.М., Подригала М.А., Волкова В.П. та інших науковців.

За визначенням ДСТУ 2886-94 стійкістю транспортного засобу під час гальмування називають його здатність зберігати заданий напрям швидкості і задану орієнтацію своїх осей [1].

На основі загальної теорії стійкості О.М. Ляпунова [2], рух механічної системи вважається стійким, якщо створені збурення незначно змінюють його траєкторію. Проте, якщо початкові відхилення з часом збільшуються, то рух можна вважати нестійким.

Описуючи поняття стійкості автомобіля, Литвинов А.С. [3] характеризує iї як сукупність параметрів, які визначають можливість його стійкого руху за всіма ступенями свободи незакріпленого твердого тіла, за винятком руху в напрямку поздовжньої осі та в напрямку, перпендикулярному до опорної площини. На думку автора стійкість руху автомобіля в напрямку його поздовжньої осі визначається його тяговими та гальмівними якостями.

Грунтовні дослідження експлуатаційних властивостей автомобілів та автопоїздів проведені доктором технічних наук, професором В.П. Сахно, В.М. Поляковим та їх учнями $[4,5,6,7,8,9,10,11$ та ін.]. Вивчаючи стійкість транспортних засобів у різних режимах руху, науковці дотримуються тлумачення стійкості, як здатності транспортного засобу зберігати заданий напрямок руху та задане положення його осей і ланок під дією зовнішніх та внутрішніх збурень. При цьому дослідники розрізняють стійкість транспортного засобу проти бічного заносу (курсова стійкість), стійкість проти перекидання (стійкість щодо кута крену) та стійкість проти складання (для автопоїздів) [11].

Вагомий внесок у дослідження стійкості руху транспортних засобів у різних режимах, зокрема i гальмівному, здійснили науковці школи доктора технічних наук, професора Гредескула А.Б., зокрема Подригало М.А. Волков В.П. та ін.

Працюючи над поліпшенням експлуатаційних властивостей автомобілів та тракторів [12], Подригало М.А. поділяе стійкість колісних машин на два види: стійкість руху та стійкість положення. На думку науковця, стійкість положення транспортного засобу полягає у стійкості проти перекидання у поздовжній та поперечній площинах. Автор зазначає, що стійкість положення є однією із властивостей стійкості руху, оскільки при втраті стійкості положення рух транспортного засобу $є$ неможливим.

Багато досліджень науковців даної школи спрямовано на забезпечення стійкості руху транспортних засобів у гальмівному режимі, шляхом регулювання та оптимального розподілу гальмівних сил по їх осях; аналіз та вдосконалення конструкції існуючих та розробку нових зразків регуляторів гальмівних сил; дослідження впливу порушень роботи гальмівних механізмів на стійкість автомобілів та тракторів при гальмуванні; дослідження впливу на експлуатаційні властивості транспортних засобів різних значень коефіцієнта використання зчіпних мас та ін. $[13,14,15,16,17$, $18,19,20$ та ін.].

Проведений аналіз робіт вітчизняних та зарубіжних науковців дозволив з'ясувати, що в своїх працях дослідники не використовують єдино прийнятого тлумачення поняття стійкості транспортного засобу в гальмівному режимі руху. В більшості, кожен з них акцентує увагу на певних 
окремих особливостях даної властивості. Проте, незважаючи на певне розходження у тлумаченні терміну, усі автори вважають стійкість важливою характеристикою транспортного засобу, яка дозволяє йому зберігати заданий напрямок руху, не відхилятися від нього під впливом прикладених сил та моментів.

Проте детальний аналіз публікацій показує, що робіт, присвячених дослідженню експлуатаційних властивостей багатоланкових автопоїздів (насамперед, триланкових) порівняно не багато. Так, у роботах [31], [32], [33], [34] розглянуто рух триланкових автопоїздів різних компонувальних схем у різних режимах руху.

Погіршення стійкості автопоїзда може призвести до фатальних наслідків. Тому є необхідність дослідження впливу компонувальних та експлуатаційних факторів на стійкість триланкового автопоїзда у гальмівному режимі.

На підставі наведеного компонувальну схему автопоїзда 3 тривісним автомобілем-тягачем, двовісним підкатним візком і тривісним напівпричепом як універсальну та перспективну (розроблено фірмами «Scania» та «Krone») обрано для дослідження його стійкості у гальмівному режимі.

Дослідженню маневреності та стійкості руху автопоїздів компонувальної схеми «автомобільтягач - двовісний підкатний візок - тривісний напівпричіп» присвячені роботи [30], [33], [35].

При розробці математичних моделей руху модульних триланкових причіпних автопоїздів у гальмівному режимі 3 урахуванням кутів встановлення його осей необхідно визначити основні кінематичні та геометричні співвідношення а також отримати рівняння для визначення нормальних реакцій опорної поверхні та бічних сил на колесах осей ланок з урахуванням їх перерозподілу по осях та бортах при гальмуванні автопоїзда у криволінійному та прямолінійному русі а також кутів відведення коліс автомобіля-тягача, підкатного візка та напівпричепа.

Крім того, завдяки введенню у математичну модель сил взаємодії кожного колеса 3 дорогою, можливо моделювання різних режимів руху автопоїзда (тягового, вільного та гальмівного), а також можливо враховувати вплив перерозподілу мас по осях та між бортами ланок автопоїзда.

Плоску математичну модель руху модульного триланкового причіпного автопоїзда у складі «автомобіль-тягач - двовісний підкатний візок - тривісний напівпричіп» розроблено у роботі [30].

У роботі [35] визначено основні кінематичні та геометричні співвідношення та розроблено рівняння для знаходження кутів відведення коліс осей ланок при русі модульного триланкового причіпного автопоїзда у складі «автомобіль-тягач - двовісний підкатний візок - тривісний напівпричіп» у гальмівному режимі.

\section{ЦІЛЬ ТА ЗАДАЧІ ДОСЛІДЖЕННЯ}

Метою дослідження є отримання рівнянь та визначення нормальних реакцій опорної поверхні на колесах осей ланок з урахуванням їх перерозподілу по осях та бортах при гальмуванні модульного триланкового причіпного автопоїзда у складі «автомобіль-тягач - двовісний підкатний візок тривісний напівпричіп» у криволінійному та прямолінійному русі.

\section{РЕЗУЛЬТАТИ ДОСЛІДЖЕНЬ}

Значний вплив на безпеку руху автопоїздів має їх стійкість у різних режимах руху. В процесі дослідження розглянемо модульний триланковий причіпний автопоїзд у складі «тривісний автомобіль-тягач - двовісний підкатний візок - тривісний напівпричіп» у гальмівному режимі руху. Для визначення нормальних реакцій опорної поверхні умовно роз'єднаємо ланки автопоїзда та введемо сили їх взаємодії в опорно-зчіпному пристрої у вертикальній площині Z (рисунок 1). Складемо рівняння рівноваги сил, що діють на ланки автопоїзда вздовж вертикальної осі, а також рівняння рівноваги моментів сил $[28,29]$.

Отримаємо:

Для автомобіля-тягача:

$$
\begin{aligned}
& \sum F_{(Z)}=Z_{01}+Z_{02}+Z_{03}-G_{0} ; \\
& \sum M_{\left(A_{01}\right)}=Z_{03}(a+b+c)+Z_{02}(a+b)-G_{0} a+F_{i 0} h_{g 0} ; \\
& \sum M_{\left(B_{0}\right)}=Z_{03} c_{2}-Z_{02} c_{1}+G_{0}\left(b+c_{1}\right)+F_{i 0} h_{g 0}-Z_{01} L_{0} .
\end{aligned}
$$

Оскільки $Z_{03}=Z_{02}=1 / 2 Z_{0} ; \quad c_{1}=c_{2}=1 / 2 c \quad m a \quad a+b+1 / 2 c=L_{0}$ то 


$$
\begin{gathered}
\sum F_{(Z)}=Z_{01}+Z_{02}+Z_{03}-G_{0} ; \\
\sum M_{\left(A_{01}\right)}=1 / 2 Z_{0}(a+b+c)+1 / 2 Z_{0}(a+b)-G_{0} a+F_{i 0} h_{g 0} ; \\
\sum M_{\left(B_{0}\right)}=G_{0}\left(b+c_{1}\right)+F_{i 0} h_{g 0}-Z_{01} L_{0} . \\
\sum F_{(Z)}=Z_{01}+Z_{02}+Z_{03}-G_{0} ; \\
\sum M_{\left(A_{01}\right)}=1 / 2 Z_{0}(2 a+2 b+c)-G_{0} a+F_{i 0} h_{g 0} ; \\
\sum M_{\left(B_{0}\right)}=G_{0}\left(b+c_{1}\right)+F_{i 0} h_{g 0}-Z_{01} L_{0} . \\
\sum F_{(Z)}=Z_{01}+Z_{02}+Z_{03}-G_{0} \\
\sum M_{\left(A_{01}\right)}=Z_{0} L_{0}-G_{0} a+F_{i 0} h_{g 0} \\
\sum M_{\left(B_{0}\right)}=G_{0}\left(b+c_{1}\right)+F_{i 0} h_{g 0}-Z_{01} L_{0} .
\end{gathered}
$$

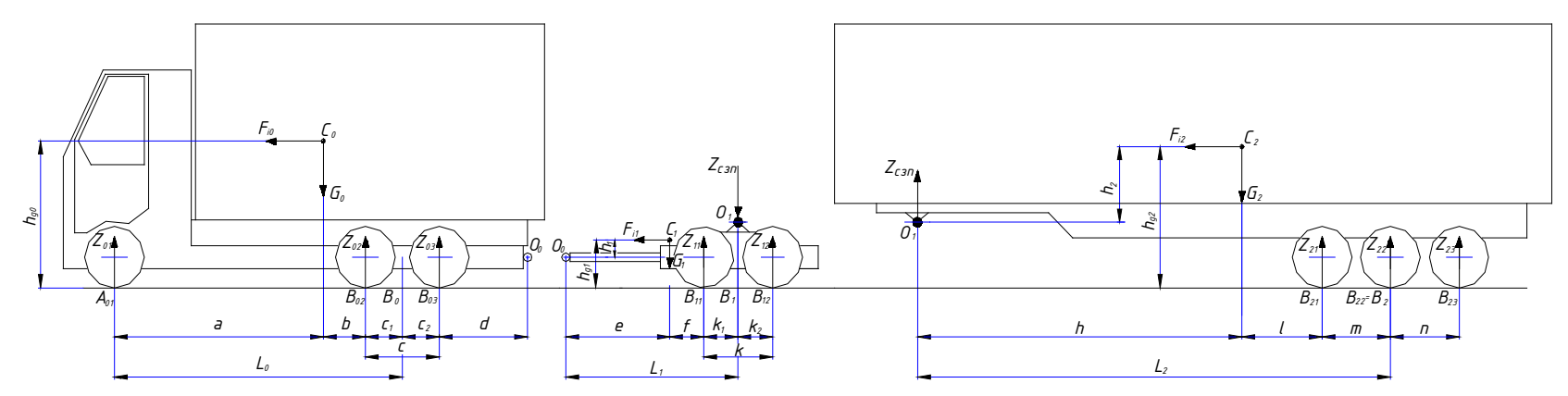

Рисунок 1 - До визначення нормальних реакцій опорної поверхні на осях ланок автопоїзда у гальмівному режимі руху

Для підкатного візка:

$$
\begin{aligned}
& \sum F_{(Z)}=Z_{11}+Z_{12}-Z_{c 3 n}-G_{1} ; \\
& \sum M_{\left(B_{1}\right)}=Z_{12} k_{2}-Z_{11} k_{1}+G_{1}\left(f+k_{1}\right)+F_{i 1} h_{g 1} ; \\
& \sum M_{\left(O_{0}\right)}=Z_{12}(e+f+k)-Z_{c 3 n} L_{1}+Z_{11}(e+f)-G_{1} e+F_{i 1} h_{1} .
\end{aligned}
$$

Оскільки $Z_{11}=Z_{12}=1 / 2 Z_{1} ; \quad k_{1}=k_{2}=1 / 2 k m a e+f+1 / 2 k=L_{1}$ то

$$
\begin{aligned}
& \sum F_{(Z)}=Z_{11}+Z_{12}-Z_{c 3 n}-G_{1} ; \\
& \sum M_{\left(B_{1}\right)}=G_{1}\left(f+k_{1}\right)+F_{i 1} h_{g 1} ; \\
& \sum M_{\left(O_{0}\right)}=Z_{1} L_{1}-Z_{c 3 n} L_{1}-G_{1} e+F_{i 1} h_{1} .
\end{aligned}
$$

Для напівпричепа:

$$
\begin{aligned}
& \sum F_{(Z)}=Z_{21}+Z_{22}+Z_{23}-G_{2}+Z_{c 3 n} ; \\
& \sum M_{\left(B_{2}\right)}=Z_{23} n-Z_{21} m+G_{2}(l+m)-Z_{c 3 n} L_{2}+F_{i 2} h_{g 2} ; \\
& \sum M_{\left(O_{1}\right)}=Z_{23}\left(L_{2}+n\right)+Z_{22} L_{2}+Z_{21}(h+l)+F_{i 2} h_{2}-G_{2} h .
\end{aligned}
$$

Оскільки $Z_{21}=Z_{22}=Z_{22}=1 / 3 Z_{2} ; m=n m a h+l+m=L_{2}$ то 


$$
\begin{aligned}
& \sum F_{(Z)}=Z_{21}+Z_{22}+Z_{23}-G_{2}+Z_{c 3 n} ; \\
& \sum M_{\left(B_{2}\right)}=G_{2}(l+m)-Z_{c 3 n} L_{2}+F_{i 2} h_{g 2} ; \\
& \sum M_{\left(O_{1}\right)}=Z_{2} L_{2}+F_{i 2} h_{2}-G_{2} h .
\end{aligned}
$$

У рівняннях (1), (2) та (3) прийняті такі позначення:

$Z_{01}, Z_{02}, Z_{03}$ - нормальні реакції опорної поверхні на передній та задніх осях автомобіля-тягача;

$Z_{11}, Z_{12}$ - нормальні реакції опорної поверхні на осях підкатного візка;

$Z_{21}, Z_{22}, Z_{23}$ - нормальні реакції опорної поверхні на осях напівпричепа;

$Z_{0}$ - вертикальне навантаження на возик автомобіля-тягача;

$Z_{1}$ - вертикальне навантаження на возик підкатного візка;

$Z_{2}$ - вертикальне навантаження на возик напівпричепа;

$Z_{\text {озn }}$ - вертикальне навантаження в опорно-зчіпному пристрої;

$G_{0}, G_{1}, G_{2}$ - сила тяжіння автомобіля-тягача, підкатного візка та напівпричепа, відповідно;

$F_{i 0}, F_{i 1}, F_{i 2}$ - сила інерції при гальмуванні у прямолінійному русі автомобіля-тягача, підкатного візка та напівпричепа, відповідно;

$h_{g}, h_{g l}, h_{g 2}$ - висота розташування центрів мас автомобіля-тягача, підкатного візка та напівпричепа, відповідно.

Вважатимемо, що навантаження $Z_{0}, Z_{1}, Z_{2}$ на візки автомобіля-тягача, підкатного візка та напівпричепа розподіляються рівномірно між його осями. Тому:

$$
\begin{aligned}
& Z_{01}+Z_{02}+Z_{03}=1 / 3 Z_{0} ; \\
& Z_{11}+Z_{12}=1 / 2 Z_{1} ; \\
& Z_{21}+Z_{22}+Z_{23}=1 / 3 Z_{2} ;
\end{aligned}
$$

Із рівнянь (1), (2) та (3), з урахуванням рівнянь (4), (5) та (6) отримаємо вирази для визначення нормальних реакцій опорної поверхні на осях автопоїзда та вертикального навантаження в сідельнозчіпному пристрої:

$$
\begin{aligned}
& Z_{01}=\frac{G_{0}\left(b+c_{1}+\frac{V_{0}}{g} h_{g 0}\right)}{L_{0}} ; \\
& Z_{02}=Z_{03}=1 / 2 Z_{0}=\frac{G_{0}\left(a-\frac{V_{0}}{g} h_{g 0}\right)}{2 L_{0}} ; \\
& Z_{11}=Z_{12}=1 / 2 Z_{1}=\frac{G_{1} L_{2}+G_{2}\left(l+m+\frac{V_{2}}{g} h_{g 2}\right)}{2 L_{2}} ; \\
& Z_{21}=Z_{22}=Z_{23}=1 / 3 Z_{2}=\frac{G_{2}\left(L_{2}-l+m+\frac{V_{2}}{g} h_{g 2}\right)}{3 L_{2}} ; \\
& Z_{c 3 n}=\frac{G_{2}\left(l+m+\frac{V_{2}}{g} h_{g 2}\right)}{L_{2}} .
\end{aligned}
$$

Зі зміною завантаження автопоїзда змінюється навантаження на опорно-зчіпний пристрій та осі транспортного засобу, що призводить до перерозподілу нормальних реакцій опорної поверхні по його осях.

При русі автопоїзда відбувається також зміна нормальних реакцій на колесах його осей. Дані зміни обумовлені дорожніми умовами, режимом руху автомобільного поїзда, його конструктивними 
особливостями. Відомо, що при розгоні, сповільненні чи русі по криволінійних траєкторіях, відбувається перерозподіл вертикальних навантажень між осями та бортами ланок транспортного засобу. Зокрема, при русі автопоїзда круговою траєкторією, під дією сил інерції виникають відцентрові сили, прикладені в центрах мас ланок автопоїзда та спрямовані в бік протилежний до центру повороту $[23,24,25,26]$. В результаті відбувається перерозподіл нормальних реакцій опорної поверхні. При цьому зовнішні щодо центру повороту колеса ланок довантажуються вертикальним навантаженням, а внутрішні - розвантажуються на таку ж величину.

По аналогії із [27] визначимо додаткові зусилля на осях автопоїзда, спричинені впливом відцентрових сил. Отримаємо:

$$
\begin{aligned}
& P_{01}=m_{01} V_{0} \omega_{0} ; \\
& P_{02}=m_{02} V_{0} \omega_{0} ; \\
& P_{03}=m_{03} V_{0} \omega_{0} ; \\
& P_{11}=m_{11} V_{1} \omega_{1} ; \\
& P_{12}=m_{12} V_{1} \omega_{1} ; \\
& P_{21}=m_{21} V_{2} \omega_{2} ; \\
& P_{22}=m_{22} V_{2} \omega_{2} ; \\
& P_{23}=m_{23} V_{2} \omega_{2},
\end{aligned}
$$

де $m_{01}, m_{02}, m_{03}, m_{11}, m_{12}, m_{21}, m_{22}, m_{23}$ - маси, що припадають на відповідні осі;

$V_{0}, V_{1}, V_{2}$ - лінійна швидкість ланок автопоїзда;

$\omega_{0}, \omega_{1}, \omega_{2}-$ кутова швидкість ланок автопоїзда.

Величину бічних зусиль, викликаних впливом відцентрових сил визначимо із рівнянь:

$$
\begin{aligned}
& P_{j 01 y}=P_{01} \operatorname{Cos}\left(\frac{\left(\theta-\delta_{1}\right)+\left(\theta^{\prime}-\delta_{1}^{\prime}\right)}{2}\right) ; \\
& P_{j 02 y}=P_{02} \operatorname{Cos}\left(\frac{\left(\beta_{2}+\delta_{2}\right)+\left(\beta_{2}+\delta_{2}^{\prime}\right)}{2}\right) ; \\
& P_{j 03 y}=P_{03} \operatorname{Cos}\left(\frac{\left(\beta_{3}+\delta_{3}\right)+\left(\beta_{3}+\delta_{3}^{\prime}\right)}{2}\right) ; \\
& P_{j 11 y}=P_{11} \operatorname{Cos}\left(\frac{\left(\beta_{4}+\delta_{4}\right)+\left(\beta_{4}+\delta_{4}^{\prime}\right)}{2}\right) ; \\
& P_{j 12 y}=P_{12} \operatorname{Cos}\left(\frac{\left(\beta_{5}+\delta_{5}\right)+\left(\beta_{5}+\delta_{5}^{\prime}\right)}{2}\right) ; \\
& P_{j 21 y}=P_{21} \operatorname{Cos}\left(\frac{\left(\beta_{6}+\delta_{6}\right)+\left(\beta_{6}+\delta_{6}^{\prime}\right)}{2}\right) ; \\
& P_{j 22 y}=P_{22} \operatorname{Cos}\left(\frac{\left(\beta_{7}+\delta_{7}\right)+\left(\beta_{7}+\delta_{7}^{\prime}\right)}{2}\right) ; \\
& P_{j 23 y}=P_{23} \operatorname{Cos}\left(\frac{\left(\beta_{8}+\delta_{8}\right)+\left(\beta_{8}+\delta_{8}^{\prime}\right)}{2}\right) .
\end{aligned}
$$

Виходячи з умов статичної рівноваги автопоїзда, та використовуючи рівняння динаміки, запишемо рівняння для визначення нормальних реакцій опорної поверхні на колесах осей автопоїзда, з урахуванням перерозподілу сил по бортах.

Розглянемо рух автопоїзда у гальмівному режимі з урахуванням сил інерції поступального та обертового рухів. При складанні рівнянь руху нехтуємо силою опору повітря, оскільки при експлуатаційних швидкостях руху автопоїздів момент від цієї сили малий, порівняно 3 іншими моментами сил. Також нехтуємо моментом від сили опору кочення коліс.

3 урахуванням прийнятих припущень отримаємо наступні рівняння:

- для автомобіля-тягача (рисунок 2): 


$$
\begin{aligned}
\sum F_{(Z)}=0: Z_{01}+Z_{01}^{\prime}+Z_{02}+Z_{02}^{\prime}+Z_{03}+Z_{03}^{\prime}-G_{0}=0 ; & \\
\sum F_{\text {mom }_{0 X} F_{i}}=0: & \left(Z_{03}+Z_{03}^{\prime}\right) L_{0}+\left(Z_{02}+Z_{02}^{\prime}\right)(a+b)-G_{0} a+P_{j 0 x} h_{g 0}=0 ; \\
& \left(Z_{03}+Z_{03}^{\prime}\right) c_{2}-\left(Z_{02}+Z_{02}^{\prime}\right) c_{1}+G_{0}\left(b+c_{1}\right)+P_{j 0 x} h_{g 0}-\left(Z_{01}+Z_{01}^{\prime}\right) L_{0}=0 ; \\
\sum F_{\text {mom }_{0 Y} F_{i}}=0: & 2 Z_{01}^{\prime} H_{01}-G_{0} H_{01}-P_{j 01 y} h_{g 0}=0 ; \\
& 2 Z_{02}^{\prime} H_{02}-G_{0} H_{02}-P_{j 02 y} h_{g 0}=0 ; \\
& 2 Z_{03}^{\prime} H_{03}-G_{0} H_{03}-P_{j 03 y} h_{g 0}=0 .
\end{aligned}
$$
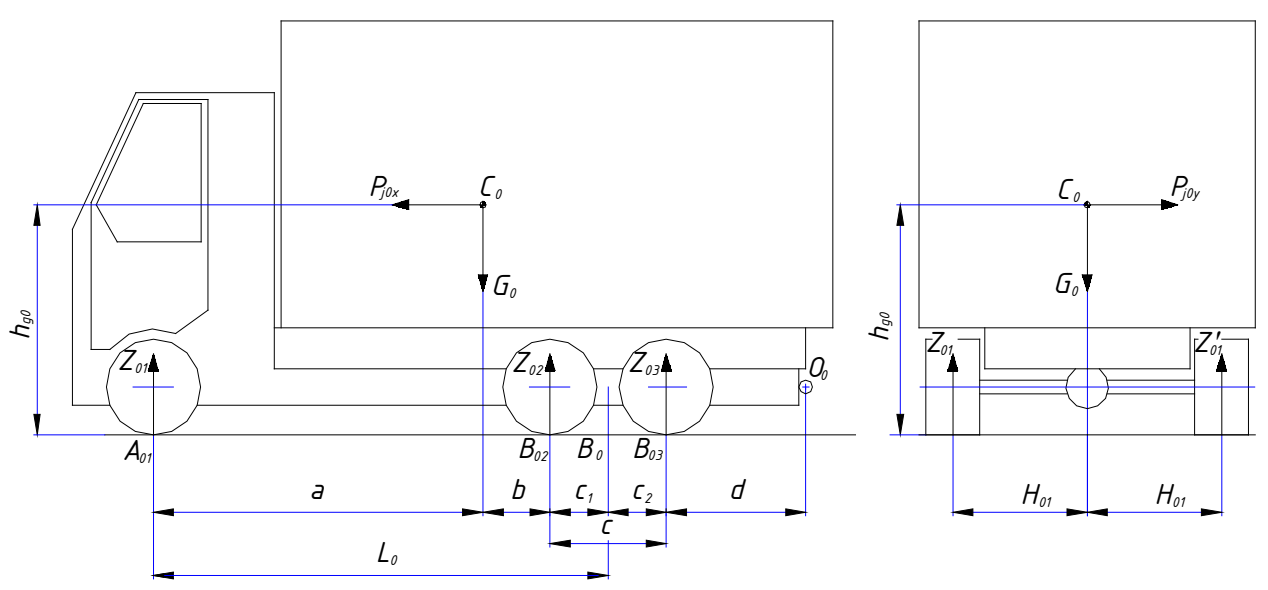

Рисунок 2 - Схема сил для визначення нормальних опорних реакцій на колесах автомобіля-тягача з урахуванням перерозподілу сил по бортах

- для підкатного візка (рисунок 3):

$$
\begin{gathered}
\sum F_{(Z)}=0: Z_{11}+Z_{11}^{\prime}+Z_{12}+Z_{12}^{\prime}-Z_{c 3 n}-G_{1}=0 ; \\
\sum F_{\text {mom }_{O X} F_{i}}=0:\left(Z_{12}+Z_{12}^{\prime}\right) k_{2}-\left(Z_{11}+Z_{11}^{\prime}\right) k_{1}+G_{1}\left(f+k_{1}\right)+P_{j 1 x} h_{g 1}=0 ; \\
\left(Z_{12}+Z_{12}^{\prime}\right)(e+f+k)-Z_{c 3 n} L_{1}+\left(Z_{11}+Z_{11}^{\prime}\right)(e+f)-G_{1} e+P_{j 1 x} h_{1}=0 ; \\
\sum F_{\text {mom }_{O Y} F_{i}}=0: 2 Z_{11}^{\prime} H_{11}-G_{1} H_{11}-P_{j 11 y} h_{g 1}=0 ; \\
2 Z_{12}^{\prime} H_{12}-G_{1} H_{12}-P_{j 12 y} h_{g 1}=0 .
\end{gathered}
$$
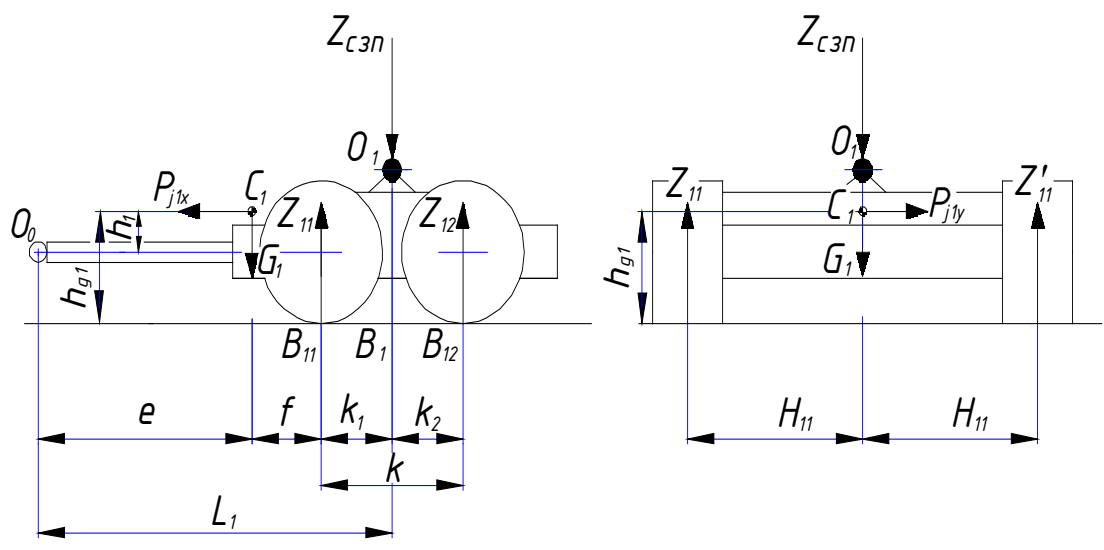

Рисунок 3 - Схема сил для визначення нормальних опорних реакцій на колесах підкатного візка з урахуванням перерозподілу сил по бортах - для напівпричепа (рисунок 4): 


$$
\begin{array}{rl}
\sum F_{(Z)}=0: Z_{21}+Z_{21}^{\prime}+Z_{22}+Z_{22}^{\prime}+Z_{23}+Z_{23}^{\prime}-G_{2}-Z_{c 3 n}=0 ; & \\
\sum F_{\text {mom }_{\text {OX }} F_{i}}=0: & \left(Z_{23}+Z_{23}^{\prime}\right) n-\left(Z_{21}+Z_{21}^{\prime}\right) m+G_{2}(l+m)-Z_{c 3 n} L_{2}+P_{j 2 x} h_{g 2}=0 ; \\
& \left(Z_{23}+Z_{23}^{\prime}\right)\left(L_{2}+n\right)+\left(Z_{22}+Z_{22}^{\prime}\right) L_{2}+\left(Z_{21}+Z_{21}^{\prime}\right)(h+l)+P_{j 2 x} h_{2}-G_{2} h=0 ; \\
\sum F_{\text {mom }_{O Y} F_{i}}=0: & 2 Z_{21}^{\prime} H_{21}-G_{2} H_{21}-P_{j 21 y} h_{g 2}=0 ; \\
& 2 Z_{22}^{\prime} H_{22}-G_{2} H_{22}-P_{j 22 y} h_{g 2}=0 ; \\
2 & 2 Z_{23}^{\prime} H_{23}-G_{2} H_{23}-P_{j 23 y} h_{g 3}=0 .
\end{array}
$$
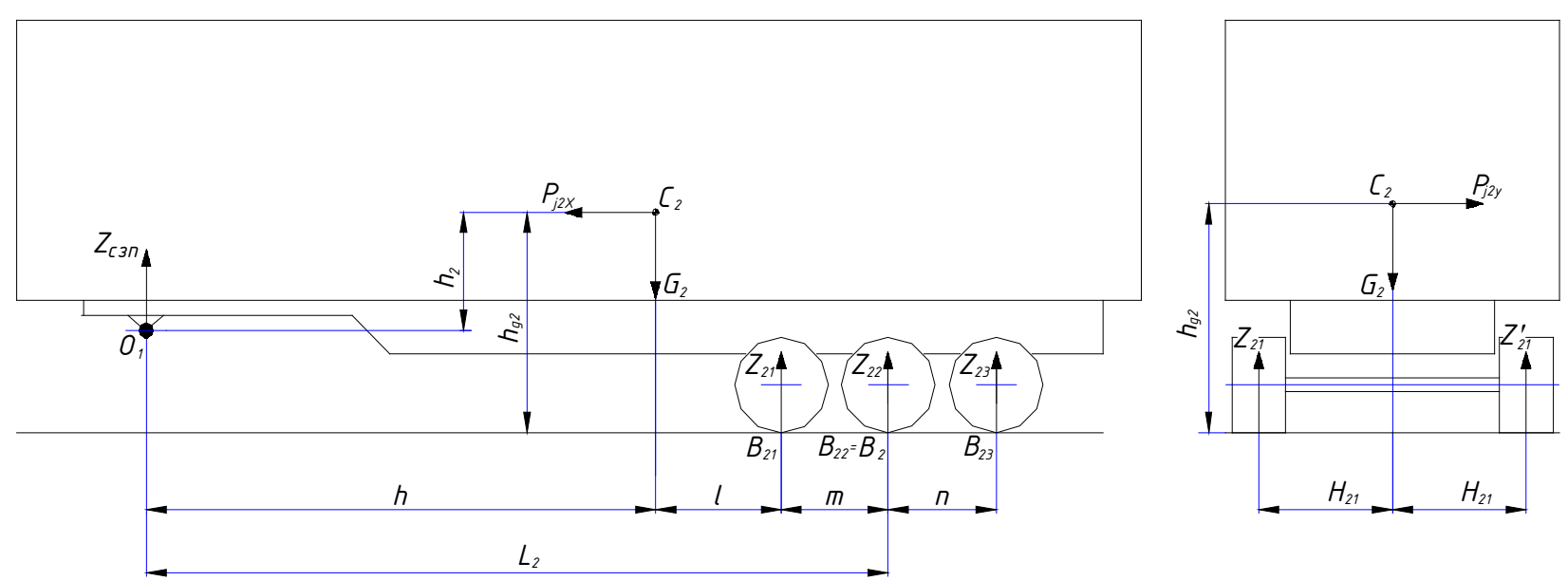

Рисунок 4 - До визначення нормальних опорних реакцій на колесах напівпричепа з урахуванням перерозподілу сил по бортах

Після обчислення рівнянь (14). (15) і (16) та після ряду перетворень, отримаємо рівняння для визначення нормальних реакцій на осях автопоїзда:

$$
\begin{aligned}
& Z_{01}=G_{0} \frac{b}{2 L_{0}}+G_{0} \frac{c_{1}}{2 L_{0}}+P_{j 0 x} \frac{h_{g 0}}{2 L_{0}}-P_{j 01 y} \frac{h_{g 0}}{2 H_{01}} ; \\
& Z_{01}^{\prime}=G_{0} \frac{b}{2 L_{0}}+G_{0} \frac{c_{1}}{2 L_{0}}+P_{j 0 x} \frac{h_{g 0}}{2 L_{0}}+P_{j 01 y} \frac{h_{g 0}}{2 H_{01}} ; \\
& Z_{02}=G_{0} \frac{a}{4 L_{0}}-P_{j 0 x} \frac{h_{g 0}}{4 L_{0}}-P_{j 02 y} \frac{h_{g 0}}{2 H_{02}} ; \\
& Z_{02}^{\prime}=G_{0} \frac{a}{4 L_{0}}-P_{j 0 x} \frac{h_{g 0}}{4 L_{0}}+P_{j 02 y} \frac{h_{g 0}}{2 H_{02}} ; \\
& Z_{03}=G_{0} \frac{a}{4 L_{0}}-P_{j 0 x} \frac{h_{g 0}}{4 L_{0}}-P_{j 03 y} \frac{h_{g 0}}{2 H_{03}} ; \\
& Z_{03}^{\prime}=G_{0} \frac{a}{4 L_{0}}-P_{j 0 x} \frac{h_{g 0}}{4 L_{0}}+P_{j 03 y} \frac{h_{g 0}}{2 H_{03}} ; \\
& Z_{11}^{\prime}=\frac{G_{1}}{4}+G_{2} \frac{l}{4 L_{2}}+G_{2} \frac{m}{4 L_{2}}+P_{j 2 x} \frac{h_{g 2}}{4 L_{2}}-P_{j 11 y} \frac{h_{g 1}}{2 H_{11}} ; \\
& Z_{12}=\frac{G_{1}}{4}+G_{2} \frac{l}{4 L_{2}}+G_{2} \frac{m}{4 L_{2}}+P_{j 2 x} \frac{h_{g 2}}{4 L_{2}}+P_{j 2 x} \frac{h_{g 2}}{4 L_{2}}-P_{j 11 y} \frac{h_{g 1}}{2 H_{11}} ; \\
& Z_{12}^{\prime}=\frac{G_{1}}{4}+G_{2} \frac{l}{4 L_{2}}+G_{2} \frac{m}{4 L_{2}}+P_{j 2 x} \frac{h_{g 2}}{4 L_{2}}+P_{j 12 y} \frac{h_{g 1}}{2 H_{12}} ;
\end{aligned}
$$




$$
\begin{aligned}
& Z_{21}=\frac{G_{2}}{6}-G_{2} \frac{l}{6 L_{2}}+G_{2} \frac{m}{6 L_{2}}+P_{j 2 x} \frac{h_{g 2}}{6 L_{2}}-P_{j 21 y} \frac{h_{g 2}}{2 H_{21}} ; \\
& Z_{21}^{\prime}=\frac{G_{2}}{6}-G_{2} \frac{l}{6 L_{2}}+G_{2} \frac{m}{6 L_{2}}+P_{j 2 x} \frac{h_{g 2}}{6 L_{2}}+P_{j 21 y} \frac{h_{g 2}}{2 H_{21}} ; \\
& Z_{22}=\frac{G_{2}}{6}-G_{2} \frac{l}{6 L_{2}}+G_{2} \frac{m}{6 L_{2}}+P_{j 2 x} \frac{h_{g 2}}{6 L_{2}}-P_{j 22 y} \frac{h_{g 2}}{2 H_{22}} ; \\
& Z_{22}^{\prime}=\frac{G_{2}}{6}-G_{2} \frac{l}{6 L_{2}}+G_{2} \frac{m}{6 L_{2}}+P_{j 2 x} \frac{h_{g 2}}{6 L_{2}}+P_{j 22 y} \frac{h_{g 2}}{2 H_{22}} ; \\
& Z_{23}=\frac{G_{2}}{6}-G_{2} \frac{l}{6 L_{2}}+G_{2} \frac{m}{6 L_{2}}+P_{j 2 x} \frac{h_{g 2}}{6 L_{2}}-P_{j 23 y} \frac{h_{g 2}}{2 H_{23}} ; \\
& Z_{23}^{\prime}=\frac{G_{2}}{6}-G_{2} \frac{l}{6 L_{2}}+G_{2} \frac{m}{6 L_{2}}+P_{j 2 x} \frac{h_{g 2}}{6 L_{2}}+P_{j 23 y} \frac{h_{g 2}}{2 H_{23}} .
\end{aligned}
$$

Навантаження на опорно-зчіпний пристрій визначимо із рівняння:

$$
Z_{c 3 n}=G_{2} \frac{l}{L_{2}}+G_{2} \frac{m}{L_{2}}+P_{j 2 x} \frac{h_{g 2}}{L_{2}} .
$$

Із використанням рівнянь (17), враховуючи (12), (13) можна визначити нормальні реакції опорної поверхні на осях автопоїзда при гальмуванні у прямолінійному русі.

\section{ОБГОВОРЕННЯ РЕЗУЛЬТАТІВ ДОСЛІДЖЕНЬ}

Результати досліджень обговорювались на XII Міжнародній науково-практичній конференції «Сучасні технології та перспективи розвитку автомобільного транспорту», місто Вінниця, Вінницький національний технічний університет, 21-23 жовтня 2019 року.

\section{ВИСНОВОК}

У роботі отримано рівняння для визначення нормальних реакцій опорної поверхні на колесах осей ланок з урахуванням їх перерозподілу по осях та бортах при гальмуванні модульного триланкового причіпного автопоїзда у складі «автомобіль-тягач - двовісний підкатний візок тривісний напівпричіп» у криволінійному та прямолінійному русі Це дозволить у теоретичних дослідженнях визначати вплив компонувальної схеми та режимів руху на стійкість автопоїзда у гальмівному режимі, врахувавши при цьому нормальні реакції опорної поверхні на колесах осей ланок з урахуванням їх перерозподілу по осях та бортах при гальмуванні.

\section{ПЕРЕЛІК ДЖЕРЕЛ ПОСИЛАННЯ}

1. Автотранспортні засоби. Гальмівні властивості. Терміни та визначення: ДСТУ 2886:94. [Чинний від 1996-01-01]. - К. : Держстандарт України, 1996. - 28 с. - (Державний стандарт України).

2. Ляпунов А.М. Общая задача об устойчивости движения / А.М. Ляпунов. - М.: ГИТТЛ, 1950. $-472 \mathrm{c}$.

3. Литвинов А.С. Управляемость и устойчивость автомобиля / А.С. Литвинов. М.: Машиностроение, 1971. -413 с.

4. Сахно В.П. Основные направления исследования устойчивости автомобиля и автопоезда / В.П. Сахно, В.Г. Вербицкий, Н.И. Мищенко // Автомобильный транспорт. - Харьков: ХНАДУ, 2001. - № 7-8. - С. 44-46.

5. Сахно В.П. До визначення показників стійкості автопоїзда-контейнеровоза / В.П. Сахно, P.М. Кузнєцов, Р.М. Марчук, В.П. Онищук // Проблеми автомобільного транспорту: Збірник наукових праць: Випуск 8. - Київ: НТУ, 2011. - С. 157-165.

6. Поляков В.М. Теоретичне дослідження впливу осьової нерівномірності гальмівних сил на стійкість автопоїзда / В.М. Поляков, Д.Ю. Приходченко, Д.А. Абрамов // Вісник СНУ імені Володимира Даля. - Луганськ: ВНТУ, 2007. - № 6 (112). - С. 59-62.

7. Сахно В.П. До визначення показників стійкості автопоїзда / В.П. Сахно, О.М. Тімков, П.О. Гуменюк, М.І. Файчук // Вісник Національного транспортного університету. - К.: НТУ, 2013. Вип. 27. - С. 31-39. 
8. Поляков В.М. Дослідження впливу геометричних параметрів триланкового автопоїзда на стійкість його руху / В.М. Поляков, Д.Ю. Приходченко, Г.М. Борисенко, М.І. Файчук // Вісник ЖДТУ: Технічні науки. - Житомир: ЖДТУ, 2010. - № 2 (53). - С. 121-126.

9. Сахно В.П. Застосування розрахункових методів до визначення показників поперечної стійкості автотранспортних засобів / В.П. Сахно, В.М. Сондак // Автошляховик України. Проблеми розвитку автомобільного транспорту. Випуск 1.- 2000. - С. 80-83.

10. Автомобили. Устойчивость: Монография / [В.Г. Вербицкий, В.П. Сахно, А.П. Кравченко, А.В. Костенко и др.]. - Луганск: Изд-во «Ноулидж», 2013. - 176 с.

11. Сахно В.П. До визначення стійкості руху автопоїзда з керованим напівпричепом / В.П. Сахно, Р.М. Кузнєцов, Р.М. Марчук, М.І. Файчук, О.А. Енглезі // Вісник Донецької академії автомобільного транспорту: Науковий журнал. - 2012. - № 4. - С. 61-67.

12. Подригало М.А. Новое в теории эксплуатационных свойств автомобилей и тракторов: Монография / М.А. Подригало. - Харьков, 2013. - 220 с.

13. Маневренность и тормозные свойства колесных машин / [М.А. Подригало, В.П. Волков, В.И. Кирчатый, А.А. Бобошко]; Под. ред. М.А. Подригало. - Харьков: Изд-во ХНАДУ, 2003. - 403 с.

14. Повышение устойчивости и управляемости колесных машин в тормозных режимах: Монография / [Е.Е. Александров, В.П. Волков, Д.О. Волонцевич и др.]; Под ред. Д.О. Волонцевича. Харьков: НТУ «ХПИ», 2007. - 320 с.

15. Устойчивость колесных машин против заноса в процессе торможения и пути ее повышения / [М.А. Подригало, В.П. Волков, В.А. Павленко и др.]; под. ред. М.А. Подригало. - Харьков: Изд-во ХНАДУ, 2006. -377 с.

16. Динамика автомобиля / [М.А. Подригало, В.М. Волков, А.А. Бобошко и др.]; под ред. М.А. Подригало. - Харьков: Изд-во ХНАДУ, 2008. - 424 с.

17. Подригало М.А. Распределение тормозных сил между осями современного АТС, учитывающее фазы процесса его торможения [Текст] / М.А. Подригало, В.И. Назаров // Автомобильная промышленность: науч. техн. журнал - 2012. - № 7. - С. 17-21.

18. Подригало М.А. Распределение реакций дороги между колесами одной оси автомобиля [Текст] / М.А. Подригало, Д.М. Клец // Вісник Східноукраїнського національного університету ім. В. Даля: наук. журнал - 2010. - № 6. - С. 46-50.

19. Подригало М.А. Влияние тормозных моментов на величину динамических вертикальных реакций дороги на осях автомобиля [Текст] / М.А. Подригало, В.И. Назаров // Автомобильная промышленность: Научно-технический журнал. - 2011. - № 8. - С. 23-25.

20. Подригало М.А. Вплив бортової нерівномірності гальмівних сил на відхилення автомобіля / М.А. Подригало, А.І. Коробко // Автомобильный транспорт. Сборник научных трудов. - Харків: ХНАДУ, 2009. - № 24. - С. 33-36.

21. Закин Я.Х. Прикладная теория движения автопоезда / Я.Х. Закин. - М.: Транспорт, 1967. $252 \mathrm{c}$.

22. Конструкции и расчет автомобильных поездов / [Я.Х. Закин, М.М. Щукин, С.Я. Марголис и др.]; под. ред. Я.Х. Закина. - Л.: Машиностроение, 1968. - 332 с.

23. Подригало М.А. Качение автомобильного колеса и определение понятия «тяговая сила» /

М.А. Подригало // Автомобильная промышленность, 2007. - № 1. - С. 25-26.

24. Бендас И.М. О торможении автомобиля на криволинейном участке пути / И.М. Бендас, Л.А. Бигунов // Автомобильный транспорт. - Вып. 14 - К.: Техника, 1977. - С. 61-65.

25. Сигал Я.Е. К теории поворота автопоезда с неуправляемыми колесами прицепного звена / Я.Е. Сигал // Автомобильная промышленность. - 1974. - № 10. - С. 23-25.

26. Лобас Л.Г. Влияние упругости катящихся колес на траектории двухзвенного автопоезда / Л.Г. Лобас // Прикл. механика. - 1986. - № 1. - С. 81 .

27. Поляков В.М. Визначення вертикальних навантажень на колеса автопоїзда / В.М. Поляков, Д.Ю. Приходченко, Д.А. Абрамов // Автошляховик України. Окремий випуск. Вісник ЦНЦ ТАУ. 2007. - С. 126-130.

28. Колісні транспортні засоби. Вимоги щодо безпечності технічного стану та методи контролювання: ДСТУ 3649:2010. - [Чинний від 2011-07-01]. - Офіц. вид. - К.: Держспоживстандарт України, 2011. - 28 с. - (Національний стандарт України).

29. Стоянов Г.А. Обобщенный критерий для оценки безопасности движения автомобиля при торможении / Г.А. Стоянов, В.В. Иванов, В.А. Илларионов // Автомобильная промышленность. 1979. - №8. - C. 19-21. 
30. Гандзюк М.О., Селезньов Е.Л., Гандзюк Д.М. Розробка плоскої математичної моделі руху модульного триланкового причіпного автопоїзда у складі «автомобіль-тягач - двовісний підкатний візок з неповоротними осями (dolly) - тривісний напівпричіп // Наукові нотатки: Міжвузівський збірник, випуск 55, Луцьк: Редакційно видавничий відділ Луцького НТУ, 2016 - С. 72-79.

31. Сахно В.П., Вороніна І.Ф., Стельмащук В.В., Поляков В.М. Вплив конструктивних і експлуатаційних факторів на показники маневреності трьохланкових автопоїздів // Автошляховик України. Окремий випуск. - 2003. Жовтень. - С. 98-101.

32. Сахно В.П., Вербицький В.Г., Вороніна І.Ф., Стельмащук В.В. До визначення показників маневреності і стійкості руху трьохланкових автопоїздів // Системні методи керування, технологія та організація виробництва, ремонту та експлуатації автомобілів. - К.:НТУ, 2003. - № 17. - С. 141-146.

33. Сахно В.П. Математичне моделювання триланкових автопоїздів в поздовжній, вертикальній і поперечній площинах / В.П. Сахно, В.М. Поляков, В.М. Глінчук // Вісник Донецької академії автомобільного транспорту. Науковий журнал, 2013. - Вип. 3. - С. 73-84.

34. Сахно В.П. Порівняльна оцінка маневреності триланкових автопоїздів різних компонувальних схем / В.П. Сахно, В.М. Поляков, Р.М. Марчук, П.О. Гуменюк // Автомобільний транспорт. Науково-виробничий журнал, 2013. - №1 (231). - С. 2-6.

35. Гандзюк М.О., Гандзюк Д.М. До питання дослідження руху модульного триланкового причіпного автопоїзда у складі «автомобіль-тягач - двовісний підкатний візок - тривісний напівпричіп» у гальмівному режимі // Д.М. Гандзюк, М.О. Гандзюк // Сучасні технології в машинобудуванні та транспорті. Науковий журнал. - Луцьк: Луцький НТУ, 2019. - №1 (12) C 29-40.

\section{REFERENCES}

1. Avtotransportni zasoby. Halmivni vlastyvosti. Terminy ta vyznachennia [Motor vehicles. Brake properties. Terms and definitions]. (1996). DSTU 2886:94 from 01 ${ }^{\text {th }}$ January 1996. Kyiv: Derzhstandart Ukraine, [in Ukrainian].

2. Liapunov, A.M. (1950). Obshchaia zadacha ob ustoichyvosty dvyzhenyia [The general problem of traffic stability]. Moscow: Gosudarstvennoe izdatelstvo tehniko-teoreticheskoy literaturyi [in Russian].

3. Litvinov, A.S. (1971). Upravlyaemost i ustoychivost avtomobilya [Controllability and stability of the vehicle]. Moscow: Mashinostroenie [in Russian].

4. Sahno, V.P., \& Verbitskiy, V.G., \& Mischenko, N.I. (2001). Osnovnyie napravleniya issledovaniya ustoychivosti avtomobilya i avtopoezda [The main directions of research on the stability of the car and road trains]. Avtomobil'nyy transport - Automobile transport, 7-8, 44-46 [in Ukrainian].

5. Sakhno, V.P., \& Kuznietsov, R.M., \& Marchuk, R.M., \& Onyshchuk, V.P. (2011). Do vyznachennia pokaznykiv stiikosti avtopoizda-konteinerovoza [To determine the stability of the road train container truck]. Problemy avtomobilnoho transport - Problems of road transport, 8, 157-165 [in Ukrainian].

6. Poliakov, V.M., \& Prykhodchenko, D.Iu., \& Abramov, D.A. (2007). Teoretychne doslidzhennia vplyvu osovoi nerivnomirnosti halmivnykh syl na stiikist avtopoizda [Theoretical study of the influence of axial non-uniformity of braking forces on the stability of the road train]. Visnyk Skhidnoukrainskoho natsionalnoho universytetu imeni Volodymyra Dalia - Bulletin of East-Ukrainian national University named after Volodymyr Dahl, 6 (112), 59-62 [in Ukrainian].

7. Sakhno, V.P., \& Timkov, O.M., \& Humeniuk, P.O., \& Faichuk, M.I. (2013). Do vyznachennia pokaznykiv stiikosti avtopoizda [To determine the performance of the road train]. Visnyk Natsionalnoho transportnoho universytetu - Bulletin of the National transport university, 27, 31-39 [in Ukrainian].

8. Poliakov, V.M., \& Prykhodchenko, D.Iu., \& Borysenko, H.M., \& Faichuk, M.I. (2010). Doslidzhennia vplyvu heometrychnykh parametriv trylankovoho avtopoizda na stiikist yoho rukhu [Investigation of the influence of geometric parameters of a three-lane road train on its stability]. Visnyk ZhDTU: Tekhnichni nauky - ZhSTU Bulletin: Technical Sciences, 2 (53), 121-126 [in Ukrainian].

9. Sakhno, V.P., \& Sondak, V.M. (2000). Zastosuvannia rozrakhunkovykh metodiv do vyznachennia pokaznykiv poperechnoi stiikosti avtotransportnykh zasobiv [The application of calculation methods to the determination of the lateral stability of vehicles]. Avtoshliakhovyk Ukrainy - Roadster of Ukraine, 1, 80-83 [in Ukrainian].

10. Verbitskiy, V.G., \& Sahno, V.P., \& Kravchenko, A.P., \& Kostenko, A.V. et al. (2013). Avtomobili. Ustoychivost [Cars. Sustainability]. Lugansk: publishing house "Knowledge" [in Ukrainian].

11. Sakhno, V.P., \& Kuznietsov, R.M., \& Marchuk, R.M., \& Faichuk, M.I., \& Enhlezi, O.A. (2012). Do vyznachennia stiikosti rukhu avtopoizda $\mathrm{z}$ kerovanym napivprychepom [To determine the stability of a semi-trailer driven semi-trailer]. Visnyk Donets'koyi akademiyi avtomobil'noho transport - Bulletin of the 
Donetsk Academy of Motor Transport, 4, 61-67 [in Ukrainian].

12. Podrigalo, M.A. (2013). Novoe v teorii ekspluatatsionnyih svoystv avtomobiley i traktorov [New in the theory of operational properties of cars and tractors]. Kharkiv: publishing house KHNADU [in Ukrainian].

13. Podrigalo, M.A., \& Volkov, V.P., \& Kirchatyiy, V.I., \& Boboshko, A.A. (2003). Manevrennost $i$ tormoznyie svoystva kolesnyih mashin [Maneuverability and braking properties of wheeled vehicles]. Kharkiv: publishing house KHNADU [in Ukrainian].

14. Aleksandrov, E.E., Volkov, V.P., Volontsevich, D.O. et al. (2007). Povyishenie ustoychivosti i upravlyaemosti kolesnyih mashin $v$ tormoznyih rejimah [Improving the stability and controllability of wheeled vehicles in braking conditions]. Kharkiv: NTU "KhPI" [in Ukrainian].

15. Podrigalo, M.A., \& Volkov, V.P., \& Pavlenko, V.A et al. (2006). Ustoychivost kolesnyih mashin protiv zanosa $v$ protsesse tormojeniya $i$ puti ee povyisheniya [The stability of wheeled vehicles against skidding during braking and ways to increase it]. Kharkiv: publishing house KHNADU [in Ukrainian].

16. Podrigalo, M.A., \& Volkov, V.P., \& Boboshko, A.A. et al. (2008). Dinamika avtomobilya [Car dynamics]. Kharkiv: publishing house KHNADU [in Ukrainian].

17. Podrigalo, M.A., \& Nazarov, V.I. (2012). Raspredelenie tormoznyih sil mejdu osyami sovremennogo ATS, uchityivayuschee fazyi protsessa ego tormojeniya [Distribution of braking forces between the axes of a modern automatic telephone exchange, taking into account the phases of the process of its braking]. Avtomobilnaya promyishlennost: nauchno tehnicheskiy jurnal - Automotive: Scientific and Technical Journal, 7, 17-21 [in Ukrainian].

18. Podrigalo, M.A., \& Klets, D.M. (2010). Raspredelenie reaktsiy dorogi mejdu kolesami odnoy osi avtomobilya [Distribution of road reactions between the wheels of one axis of the car]. Visnyk Skhidnoukrainskoho natsionalnoho universytetu imeni Volodymyra Dalia - Bulletin of East-Ukrainian national University named after Volodymyr Dahl, 6, 46-50 [in Ukrainian].

19. Podrigalo, M.A., \& Nazarov, V.I. (2011). Vliyanie tormoznyih momentov na velichinu dinamicheskih vertikalnyih reaktsiy dorogi na osyah avtomobilya [The influence of braking moments on the magnitude of the dynamic vertical reactions of the road on the axles of the car]. Avtomobilnaya promyishlennost: nauchno tehnicheskiy jurnal - Automotive: Scientific and Technical Journal, 8, 23-25 [in Ukrainian].

20. Podrigalo, M.A., \& Korobko, A.I. (2009). Vplyv bortovoi nerivnomirnosti halmivnykh syl na vidkhylennia avtomobilia [Effect of on-board non-uniformity of braking forces on the deflection of the car]. Avtomobil'nyy transport - Automobile transport, 24, 33-36 [in Ukrainian].

21. Zakin, YA.H. (1967). Prikladnaya teoriya dvijeniya avtopoezda [Applied Theory of Trains]. Moscow: Transport [in Russian].

22. Zakin, YA.H., \& Schukin, M.M., \& Margolis, S.YA. et al. (1968). Konstruktsii i raschet avtomobilnyih poezdov [Design and calculation of road trains]. Leningrad: Mashinostroenie [in Russian].

23. Podrigalo, M.A. (2007). Kachenie avtomobilnogo kolesa i opredelenie ponyatiya «tyagovaya sila» [Rolling a car wheel and the definition of "traction force"]. Avtomobilnaya promyishlennost: nauchno tehnicheskiy jurnal - Automotive: Scientific and Technical Journal, 1, 25-26 [in Ukrainian].

24. Bendas, I.M., \& Bigunov, L.A. (1977). O tormojenii avtomobilya na krivolineynom uchastke puti [About car braking on a curved stretch of track]. Avtomobil'nyy transport-Automobile transport, 14, 61-65 [in Ukrainian].

25. Sigal, YA.E. (1974). K teorii povorota avtopoezda s neupravlyaemyimi kolesami pritsepnogo zvena [On the theory of turning a road train with unmanaged wheels of a trailed link]. Avtomobilnaya promyishlennost: nauchno tehnicheskiy jurnal - Automotive: Scientific and Technical Journal, 10, 23-25 [in Ukrainian].

26. Lobas L.G. (1986). Vliyanie uprugosti katyaschihsya koles na traektorii dvuhzvennogo avtopoezda [The effect of the elasticity of rolling wheels on the trajectory of a two-link road train]. Prikladnaya mehanika - Applied mechanics, 1.81 [in Ukrainian].

27. Poliakov, V.M., \& Prykhodchenko, D.Iu., \& Abramov, D.A. (2007). Vyznachennia vertykalnykh navantazhen na kolesa avtopoizda [Determination of vertical loads on the wheels of the road train]. Avtoshliakhovyk Ukrainy. Okremyi vypusk - Roadster of Ukraine. Installment, 126-130 [in Ukrainian].

28. Kolisni transportni zasoby. Vymohy shchodo bezpechnosti tekhnichnoho stanu ta metody kontroliuvannia [Wheeled vehicles. Requirements for the safety of the technical condition and methods of control]. (2011). DSTU 3649:2010 from 07 th January 2011. Kyiv: Derzhstandart Ukraine, [in Ukrainian].

29. Stoyanov, G.A., \& Ivanov, V.V., \& Illarionov, V.A. (1979). Obobschennyiy kriteriy dlya otsenki bezopasnosti dvijeniya avtomobilya pri tormojenii [Generalized criterion for assessing the safety of the 
vehicle during braking]. Avtomobilnaya promyishlennost: nauchno tehnicheskiy jurnal - Automotive: Scientific and Technical Journal, 8, 19-21 [in Ukrainian].

30. Handziuk, M.O., \& Seleznov, E.L., \& Handziuk, D.M. (2016). Rozrobka ploskoi matematychnoi modeli rukhu modulnoho trylankovoho prychipnoho avtopoizda u skladi «avtomobil-tiahach - dvovisnyi pidkatnyi vizok z nepovorotnymy osiamy (dolly) - tryvisnyi napivprychip [Development of flat mathematical model of motion of the module three-unit towed lorry convoy in composition a «car-tractor is a biaxial light cart with irrevocable axes (dolly) is a triaxial semitrailer]. Naukovi notatky - The Scientific notes, 55, $72-79$ [in Ukrainian].

31. Sakhno, V.P., \& Voronina, I.F., \& Stel'mashchuk, V.V., \& Polyakov, V.M. (2003). Vplyv konstruktyvnykh i ekspluatatsiynykh faktoriv na pokaznyky manevrenosti tr'okhlankovykh avtopoyizdiv [Influence of constructive and operational factors on indicators of maneuverability of three-axle road trains]. Avtoshlyakhovyk Ukrayiny - SUV of Ukraine, Installment, 98-101 [in Ukrainian].

32. Sakhno, V.P., \& Verbyts'kyy, V.H., \& Voronina, I.F., \& Stel'mashchuk, V.V. (2003). Do vyznachennya pokaznykiv manevrenosti i stiykosti rukhu tr'okhlankovykh avtopoyizdiv [To determination of indicators of maneuverability and stability of three-lane trains]. Systemni metody keruvannya, tekhnolohiya ta orhanizatsiya vyrobnytstva, remontu ta ekspluatatsiyi avtomobiliv - System management methods, technology and organization of production, repair and operation of cars, 17, 141-146 [in Ukrainian].

33. Sakhno, V.P., \& Poliakov, V.M., \& Hlinchuk, V.M. (2013). Matematychne modelyuvannya trylankovykh avtopoyizdiv $\mathrm{v}$ pozdovzhniy, vertykal'niy i poperechniy ploshchynakh [Mathematical modeling of three-axle road trains in longitudinal, vertical and transverse planes]. Visnyk Donets'koyi akademiyi avtomobil'noho transport - Bulletin of the Donetsk Academy of Motor Transport, 3, 73-84 [in Ukrainian].

34. Sakhno, V.P., \& Poliakov, V.M., \& Marchuk, R.M., \& Humeniuk P.O. (2013). Porivnialna otsinka manevrenosti trylankovykh avtopoizdiv riznykh komponuvalnykh skhem [Comparative assessment of maneuverability of three-lane road trains of different layout schemes]. Avtomobil'nyy transport - Automobile transport, 1 (231), 2-6 [in Ukrainian].

35. Handziuk, M.O., \& Handziuk, D.M. (2019). Do pytannia doslidzhennia rukhu modulnoho trylankovoho prychipnoho avtopoizda u skladi «avtomobil-tiahach - dvovisnyi pidkatnyi vizok - tryvisnyi napivprychip» u halmivnomu rezhymi [On the question of the study of the motion of a modular three-link trailer trainset in the composition "tractor-truck - two-axle rolling cart - three-axle semi-trailer" in the braking mode]. Suchasni tekhnolohii v mashynobuduvanni ta transporti. Naukovyi zhurnal - Modern technologies in mechanical engineering and transport. Scientific journal, 1 (12), $29-40$ [in Ukrainian].

\section{Gandziuk, N. Gandziuk, V. Stelmashchuk Determination of normal reactions of the supporting surface during the movement of a modular three-link trailed road train as part of a "car-tractor - two-axle trolley-three-axle semi-trailer" in the braking mode.}

An efficient means of reducing the number of vehicles while maintaining the volume of cargo transportation is the use of trains. Nowadays, trains are used in many countries around the world. Due to their relative structural simplicity and shorter length with the same load capacity, and taking into account a number of other advantages, truck trains have received considerable recognition and are the most widespread in providing freight transportation.

Given the increasing intensity of traffic on modern highways, it is necessary to increase the safety of vehicles in order to avoid accidents that result in deterioration of human health and significant material losses in the damage of vehicles and goods. This issue is particularly acute in the case of car trains, the process of which is much more complicated than the single car. It is necessary for the braking system to regulate the speed of the road train over a wide range, to counter skidding, as well as to prevent the assembly of links of the vehicle and its collision with other cars, that is, providing adequate stability. The driver must as far as possible control the behavior of the vehicle while driving and, if necessary, stop it quickly and safely.

Therefore, improving the performance of road trains in modern driving conditions is one of the priority tasks to ensure a high level of safety of their operation with maximum efficiency of use. Achieving these requirements is possible only subject to possible changes in the technical condition of road trains during operation. In particular, considerable attention should be paid to changes that can occur in the braking system of the link of the train, which can lead to the violation of optimal indicators of regulation and distribution of the braking forces on the axles and sides of the vehicle, which inevitably leads to loss of stability of its movement, even at low speeds, especially at maximum load. 
The solution to these problems is impossible without the development of a mathematical model of motion of a modular three-link trailer road train, which would take into account the basic kinematic and geometric ratios, angles of installation of axles, normal reactions of the supporting surface and lateral forces on the wheels of the axles of the links, taking into account their redistribution at axles self-propelled trains in curvilinear and straight-line traffic, as well as the angles of removal of the wheels of the tractor-car, the rolling cart and the semi-trailer.

That is why this work is devoted to the determination of the normal reactions of the reference surface when driving a modular three-link trailer train in the composition "tractor-truck - two-axle rolling cart three-axle semi-trailer" in braking mode.

Keywords: road train; modular three-link trailer trains; layout diagram; trailed link; trailer; semitrailer; rolling cart; mathematical model; operational properties; stability; support surface; normal reactions; brake mode.

ГАНДЗЮК Дмитро Миколайович, магістр із спеціальності «Автомобілі і автомобільне господарство», аспірант Луцького національного технічного університету, е-mail: Gandzyukd@gmail.com.

ГАНДЗЮК Микола Олександрович, кандидат технічних наук, доцент кафедри автомобілів і транспортних технологій Луцького національного технічного університету, e-mail: Gandzyuk64.MG@gmail.com. http://orcid.org/0000-0002-3552-4256.

СТЕЛЬМАЩУК Валерій Віталійович, кандидат технічних наук, доцент кафедри автомобілів і транспортних технологій Луцького національного технічного університету, e-mail: Val.stelmashchuk@gmail.com.https://orcid.org/0000-0003-3813-3143.

Dmitriy HANDZIUK, Magistr of Transport, Postgraduate Student of Lutsk National Technical University, e-mail: Gandzyukd@gmail.com.

Mykola GANDZIUK, Ph.D in Engeneering, associate professor of automobiles and transport technologies department, Lutsk National Technical University, e-mail: Gandzyuk64.MG@gmail.com. http://orcid.org/0000-0002-3552-4256.

Valery STELMASHCHUK, Ph.D in Engeneering, associate professor of automobiles and transport technologies department, Lutsk National Technical University, e-mail: Val.stelmashchuk@gmail.com. https://orcid.org/0000-0003-3813-3143. 